\title{
legelivet
}

På disse sidene i Tidsskriftet - legelivet - finner du stoff om legers liv.

Her er det presentasjon av arbeidssteder, nyhetssaker, nye doktorgrader,

nye spesialister og minneord. Alt samlet på ett sted - så du kan følge enda bedre med.

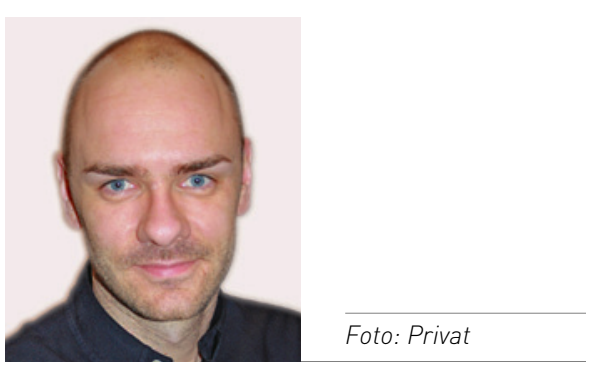

Petter Morten Pettersen (f. 1986) er turnuslege ved Sykehuset Østfold og medarbeider i Tidsskriftet.

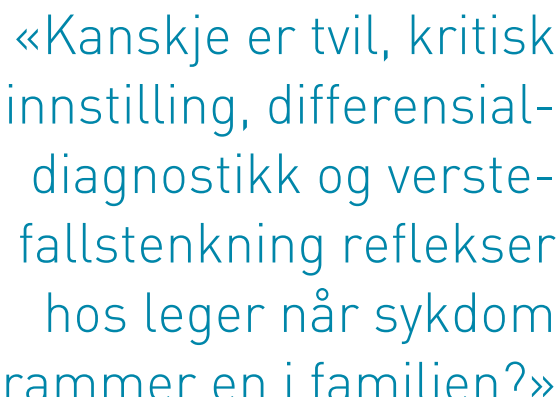

rammer en i familien?»

\section{Når leger blir pårørende}

Leger kan være vanskelige og kravstore pårørende. Trumfer følelser og bekymring rasjonalitet og trygghet hos leger som opplever sykdom i sin egen familie?

Til daglig er jeg omgitt av dyktige kolleger. Jeg tror de forsøker å yte sitt beste overfor alle pasienter, uavhengig av om en legekollega er pasientens pårørende.

Som medisinstudent og lege har jeg flere ganger opplevd at mennesker i nær familie blir pasienter ved sykehuset der jeg jobber. Sykdom hos dem som står en nærmest, er utfordrende nok i seg selv. Å stå i hvitt på jobb da ens egne kom til sykehus, syntes jeg var vanskelig.

Det var utfordrende da mine kolleger skulle ta vare på de kjæreste jeg har. Spesielt vanskelig var det å balansere kollegalojalitet og passivitet mot kritiske spørsmål og delaktighet. Ukollegial var det siste jeg ønsket å være, og som fersk lege er det vanskelig å stille spørsmål ved det mer erfarne kolleger har besluttet. Samtidig kjente jeg som pårørende en redsel for at mine egne ikke skulle få den mest optimale helsehjelpen, var bekymret for at de skulle bli offer for sene avgjørelser i et travelt akuttmottak, fryktet for feildiagnostisering og feilbehandling. Kanskje er tvil, kritisk innstilling, differensialdiagnostikk og verstefallstenkning reflekser hos leger når sykdom rammer en i familien? Jeg har fått inntrykk av at mange kolleger har kjent på lignende dilemmaer.

Jeg håper ikke leger som pårørende innebærer forskjellsbehandling i diagnostikk og behandling. Dersom våre pårørende favoriseres i den norske helsevesenet, er vi selvsagt på villspor. Sannsynlig stiller ressurskrevende pårørende strengere krav til helsevesenet. Og det er rimelig å anta at leger er den ypperste representant for den ressurssterke pårørendegruppen. De kjenner sin arbeidsplass og systemenes styrker og svakheter. Da kan det være vanskelig å la være å påvirke den sedvanlige prosessen, unngå å la kollegaen jobbe i uvitenhet om at det er en i din familie som er syk. Vi vil vel alle det beste for våre egne.

Når leger ikke er på sitt skarpeste, når autopiloten og likegyldigheten sniker seg innpå slitne mennesker på jobb, tror jeg det kan være lurt å huske at det finnes mange leger som er pårørende. Vi må kunne møte våre kolleger $\mathrm{i}$ den rollen med rak rygg og ren samvittighet, også når vår legekollega først gjør seg til kjenne utskrivningsdagen.

Petter Morten Pettersen

pettermortenpettersen@gmail.com 